3. Roberta Gualtierotti, Angelo Valerio Marzano, Francesco Spadari, Massimo Cugno. Main Oral Manifestations in Immune-Mediated and Inflammatory Rheumatic Diseases. Journal of Clinical Medicine. 2019. № 8. P. 1-19.

4. Robert JR Reilly, William Johnston, Shauna Culshaw. Autoimmunity and the Oral Cavity. Current Oral Health Reports. 2019. № 6. P. 1-8.

5. Банченко Г. В., Максимовский Ю. М., Гринин В. М. Язык «зеркало» организма : клиническое руководство для врачей. Москва : ЗАО «Бизнес Центр «Стоматология», 2000. 407 с.

6. Модина Т. В., Шумський А. В., Мамаева Е. В., Железняк В. А. Диагностика и лечение различных форм десквамативного глоссита. Becтник современной клинической медициины. 2010. Т. 3, № 1. С. 26-32.

DOI https://doi.org/10.30525/978-9934-26-113-8-12

\title{
ORAL MANIFESTATION OF PATIENT WITH COVID-19: CASE REPORT OF NECROTIZING ULCERATIVE GINGIVITIS
}

\author{
Samoilenko A. V. \\ Doctor of Science in Medicine, Professor, \\ Head of the Department of therapeutic dentistry \\ Dnipro State Medical University \\ Oryshchenko V. Yu. \\ Candidate of Medical Sciences, \\ Associate Professor at the Department of therapeutic dentistry \\ Dnipro State Medical University \\ Strelchenia T. N. \\ Candidate of Medical Sciences, \\ Associate Professor at the Department of therapeutic dentistry \\ Dnipro State Medical University \\ Dnipro, Ukraine
}

Coronavirus disease 2019 (COVID-19) is a respiratory illness caused by the severe acute respiratory syndrome coronavirus 2 (SARS-CoV-2). This infection has a broad spectrum of presentations that can range from asymptomatic disease to fatal acute respiratory distress syndrome[1, p. 143]. 
Although Covid-19 is primarily a respiratory disease, the emerging literature on patients with COVID-19 shows that the oral health of COVID-19 patients can be affected by the SARS-CoV-2. Some oral signs and symptoms such as dysgeusia, petechiae, candidiasis, HSV-1 infection, geographic tongue, thrush-like ulcers, among others have recently been described [2, p. 326].

Angiotensin converting enzyme-2 (ACE-2) has been considered the main receptor for the virus entry into target cells. In recent published data, oral epithelial cells have been found to highly express ACE-2[3, p.8]. Therefore, cells with ACE-2 receptor distribution may become host cells for the virus and further cause inflammatory reactions in related organs and tissues. According to Badran Z. et al., 2020[4, p. 109907], periodontal pockets also could be a niche for SARS-CoV-2 virus infection. Periodontal pockets are known to be compatible environments for viral infection such as, Herpes simplex virus, Epstein-Barr virus, Human Cytomegalovirus[5, p.243].

The aim of this abstract was to report a case of acute necrotizing ulcerative gingivitis in COVID-19 patient treated at the Therapeutic Dentistry Department at the Dnipro State Medical University, Ukraine.

The case was a 32-year-old woman, not known to have any chronic medical condition, presented with severe gingival pain, spontaneous bleeding for 2 days. Normal oral hygiene measures and mastication became difficult. Her subject systemic symptoms included: temperatures approaching $37^{\circ} \mathrm{C}$, headache, fatigue, nausea, and lack of appetite. During the anamnesis the patient indicated that systemic symptoms presented about week prior to any oral symptoms.

On examination, she had bilateral submandibular lymphadenopathy, halitosis. Clinical intraoral examination revealed significant plaque accumulation on the surfaces of all teeth as well as generalized erythematous and edematous gingivae with ulceration and necrosis of the interdental papillae in mandibular labial sextant. Bleeding was evident from the gingival sulcus without provocation, and there was no detectable attachment loss. Thrush lesions on the middle third of the tongue were also observed.

High levels of Prevotella intermedia, Treponema denticola, Bacteroides intermedius and Fusobacterium nucleatum were detected by polymerase chain reaction (PCR) in isolate of the gingival sulcus.

A clinical diagnosis of necrotizing ulcerative gingivitis (NUG) was made.

The patient was prescribed $400 \mathrm{mg}$ Metronidazole three times daily for 5 days, Iruxol gum application twice daily for 7 days and $0.05 \%$ Chlorhexidine gluconate mouthrinse twice daily for 20 days. Mechanical periodontal procedures were not performed due to suspected COVID-19 because the patient had known infected contacts. Her brother was diagnosed with COVID-19 two weeks before. 
The patient was proposed SARS-CoV-2 PCR testing and advised to call her primary care doctor. PCR assay resulted positive for COVID-19, so the patient was confined to their homes for ten days to prevent the spread of the virus. She also had been taking the Vit D, C, Zinc, Ibuprofen which was taken for headache, and Azithromycin which she took in twice for five days prescribed by her primary care doctor.

Follow-up occurred throughout treatment by dental teleconsultation. The patient is asked for authorization to observe the injury through the mobile phone and her husband is asked to take photographs of lesion. These photos were immediately sent to us by Viber.

After 7 days, oral lesions were healed and regular oral hygiene methods were resumed by the patient. Systemic symptoms regressed on day 14, and the patient was recalled for periodontal treatment to remove supragingival plaque and calculus.

In conclusion, since the oral health of COVID-19 patients can be affected by the infection, there is still doubt whether these manifestations could be a typical pattern resulting from the direct viral infection. However, some researchers assume that oral lesions contributed to COVID-19 are based on the assumption of the thrombogenic effects of SARS-CoV-2 [6, p. 772].

But it is more likely that the nature of the SARS-CoV-2 virus and even stress could put the control of the immune system at risk. A certain state of immune dysregulation may lead to opportunistic infections such as NUG [7, p. 325]. The presence of NUG in the patient have been reported in other studies reporting oral manifestations associated with human immunodeficiency virus [8, p.20], therefore, it is possible that advances with HIV can be applied to this new virus.

So, the molecular mechanisms of SARS-CoV-2 infection pathogenesis and virus-host interactions remain largely unclear. Studies of its role in oral disorders are yet to be elucidated. Oral lesions could be a possible clinical characteristic of COVID-19.

\section{References:}

1. Hu B, Guo H, Zhou P, Shi ZL. Characteristics of SARS-CoV-2 and COVID-19. Nat Rev Microbiol. 2021. №19(3). P.141-154.

2. Amorim Dos Santos J, Normando AGC, Carvalho da Silva RL, De Paula RM, Cembranel AC, Santos-Silva AR, Guerra ENS. Oral mucosal lesions in a COVID-19 patient: New signs or secondary manifestations? Int J Infect Dis. 2020. №97. P.326-328.

3. Xu H, Zhong L, Deng J, Peng J, Dan H, Zeng X, Li T, Chen Q. High expression of ACE2 receptor of 2019-nCoV on the epithelial cells of oral mucosa. Int J Oral Sci. 2020. №12.(1). P. 8. 
4. Badran Z, Gaudin A, Struillou X, Amador G, Soueidan A. Periodontal pockets: A potential reservoir for SARS-CoV-2? Med Hypotheses. 2020. №143. P.109907.

5. Miller CS. Viruses: are they really culprits for periodontal disease? A critical review. J Investig Clin Dent. 2014. №5(3). P.243.

6. Ansari R, Gheitani M, Heidari F, Heidari F. Oral cavity lesions as a manifestation of the novel virus (COVID-19). Oral Dis. 2021. № 3. P.771-772.

7. Dufty J, Gkranias N, Donos N. Necrotising Ulcerative Gingivitis: A Literature Review. Oral Health Prev Dent. 2017. №15(4). P.321-327.

8. Grando LJ, Yurgel LS, Machado DC, Silva CL, Menezes M, Picolli C. Manifestações estomatológicas, contagem de linfócitos T-CD4+ e carga viral de crianças brasileiras e norte-americanas infectadas pelo HIV [Oral manifestations, CD4+ T-lymphocytes count and viral load in Brazilian and North-American HIV-infected children]. Pesqui Odontol Bras. 2002. № 16(1).P. 18-25.

DOI https://doi.org/10.30525/978-9934-26-113-8-13

\title{
THE STATISTIC INVESTIGATION ON APPROACHES IN SELECTION DIFFERENT DIAGNOSTIC METHODS IN THE TREATMENT OF PATIENTS WITH GENERALIZED PERIODONTITIS USED BY DENTISTS. RESULTS OF ANONYMOUS QUESTIONNAIRES
}

\author{
Symonenko R. V. \\ Candidate of Medical Science, \\ Assistant at the Department of Prosthodontic Dentistry \\ Bogomolets National Medical University \\ Kofanov V. O. \\ Student \\ Bogomolets National Medical University \\ Kyiv, Ukraine
}

One of the most widespread diseases after caries are periodontal diseases, according to the WHO [1, s.14]. Still, generalized periodontitis relates to diseases that have the least successful treatment efficacy. The lack of a clear understanding of the causality of the periodontal disease progression 